\title{
1AZAM Aiding Low-Income Households in Malaysia
}

\author{
Radieah Mohd Nor, Sharifah Nurlaili Farhana Syed Azhar \\ Centre for Global Sustainability Studies (CGSS), Level 5, Hamzah Sendut Library, Universiti Sains Malaysia, Penang, Malaysia \\ Email: radieah@usm.my, sh.nurlaili@usm.my
}

How to cite this paper: Nor, R.M. and Azhar, S.N.F.S. (2016) 1 AZAM Aiding LowIncome Households in Malaysia. Journal o1 Human Resource and Sustainability Studies, 4, 293-304.

http://dx.doi.org/10.4236/jhrss.2016.44029

Received: August 18, 2016

Accepted: November 1, 2016

Published: November 4, 2016

Copyright $\odot 2016$ by authors and Scientific Research Publishing Inc. This work is licensed under the Creative Commons Attribution International License (CC BY 4.0).

http://creativecommons.org/licenses/by/4.0/

\begin{abstract}
Poverty has always been a major topic of discussion throughout the world. Based on the studies that have been conducted in Malaysia, they only take about 44 years to reach $1 \%$ incidence of poverty in 2014 . While in 1970 , the incidence of poverty was 49.3\%. Malaysian government's efforts to eradicate poverty of its people can be seen when the government attempted through the Government Transformation Programme (GTP) through the National Key Result Areas (NKRA) with the Ministry of Women, Family and Community Development (KPWKM) becomes as the main driver. Through KPWKM, $1 A Z A M$ (1Aim) was launched. The program identified four main areas namely $A Z A M$ Tani (Farms Aim), AZAM Khidmat (Services Aim), $A Z A M$ Kerja (Works Aim) and AZAM Niaga (Business Aim) to help the poor Malaysians out of the group.
\end{abstract}

\section{Keywords}

$1 A Z A M$, Malaysia, The Eradication of Poverty

\section{Introduction}

Malaysia is located in the Southeast Asia where the estimated population in 2013 according to The World Bank is approximately about 29.72 million people [1]. Though Malaysia is considered as a developing country with an upper middle income and had developed extensively in terms of globalization, poverty however continues to be a huge concern among the citizens. While urbanization has rose drastically throughout the country, there are still quite a number of people who earn less than RM1000 and RM 1500 per month for both rural and city areas, respectively.

The Malaysian Economic Planning Unit (EPU) employed the concept of the Poverty Line Income (PLI) to measure poverty through the absolute poverty concept. PLI consists of two components, which are the Food PLI and Non-food PLI. PLI is determined 
separately for each household in the Household Income Survey according to household size, demographic composition and location (state and strata). Therefore, each household has its own PLI value based on the demographic characteristics of each household. A person or household is considered poor if its monthly household income is less than its PLI, meaning that the households lack resources to meet the basic needs of all its members. According to the statistic provided by the Department of Statistic Malaysia, the percentage of poor households has decreased from 1997 (2.1\% in urban and 10.9\% in rural areas) to 2009 (1.7\% in urban and $8.4 \%$ in rural areas).

According to Gopal and Malek [2], various poverty alleviation strategies and programmers were implemented in the context of growth and distribution since the era of the New Economic Policy in Malaysia (NEP, 1971 until 1990). Moreover, significant reduction in the incidence of poverty was achieved with the growing economy [3]. Nevertheless, previous study done by Ragayah [4] throughout the year's shows that the incidence of poverty was reduced from 52.4 percent in 1970 to 3.8 percent in 2009. Between year 1999 and 2007, even income worsened for all states in Malaysia except for Kelantan, Kedah, Melaka and Johor [4]. This is mainly because almost all the agricultural land space-paddy plantation inhabited by the poor Malays-was neglected as it does not bring high economic returns to the colonial government [5]. Thus, the poverty of the Malay-populated rural sector became aggravated.

Ministry of Women, Family and Community Development (KPWKM), Malaysia is one of the leading ministries in the National Key Result Areas (NKRA) aimed to improve the standard of living for low-income people. The ministry has highlighted various efforts and initiatives to improve the standard of living of extreme poor, poor and low-income households. One of the NKRA initiatives is to improve the standard of living for the extreme poor, poor and low-income households. One of the NKRA initiatives is through $1 A Z A M$, a program of income generation through economic activities such as business, sewing, farming and small-scale agriculture.

$1 A Z A M$ Program refers to the types of jobs in the field of employment, services, agriculture and businesses that are identified as appropriate and can be proceed to generate and increase the income of the poor. Currently, there are four main programs under the $1 A Z A M$ program which are $A Z A M$ Kerja (Aim Works), AZAM Tani (Aim Agricultural), $A Z A M$ Niaga (Aim Business) and $A Z A M$ Khidmat (Aims Services).

\section{(a) Individual qualification for $1 A Z A M$}

The Malaysia government has set a requirement eligibility standard for applicants whom wish to apply and join $1 A Z A M$ program. These groups of people who wish to apply and join $1 A Z A M$ program must come from the extreme poor and poor groups whom had registered in the eKasih, a government database system for the needy people in Malaysia. EKasih system is a database system for poor families that is created at the national level to help design, implement and monitor poverty program. EKasih system was established following the decision of the Malaysia Government Cabinet on October 31, 2007 and meeting of the Chief Ministers on November 1, 2007. Starting from these results, it was started to develop in-house by the Implementation Coordination Unit 
(ICU) of the Prime Minister Department and first used in June, 2008. Data and information included in eKasih is based on the Census of Poor Households (IRM). BIRM is a program with the approach of the census of households and non-individuals. It is run by the Department of Statistics Malaysia Official with census results submitted to the ICU Prime Minister Department as a key input to eKasih [6].

In addition, the mechanism of open enrolment in eKasih is also the source of data and information contained in eKasih database system. Households verified in the field and meet the eligibility criteria of eKasih are eligible for inclusion into eKasih. In addition to those who meet the eligibility criteria of poverty status based on per capita household PLI 2007, eligibility for registration and included in the eKasih are households with an income of less than RM 1000 per month for the rural population and RM 1500 a month for residents in the city.

Detailed registration will be done by the enumerator for the purpose of verification and then to be registered in the eKasih database system confirmed by the focus group, comprising the District Office and the ICU at the state level. Qualified individuals may present to the nearby State Development Office to enroll them into the eKasih system before any $1 A Z A M$ can be offered to them. Only registered and authorized applications will be considered for $1 A Z A M$ program.

\section{(i) $A Z A M$ Kerja}

One of the first programs that are offered under $1 A Z A M$ is known as $A Z A M$ Kerja. $A Z A M$ Kerja offers opportunities to generate income through work placements. $A Z A M$ Kerja focuses on various areas of work for those who are productive and has low education qualifications or for those who are without talented skills, both soft and hard skills. Participants in this program will undergone a training program in various skills that will enable them to be accepted and get hired into suitable employment such as waitress, a fast food restaurant workers and hotel workers. The program is implemented in collaboration with the Ministry of Human Resources.

The Ministry of Human Resources has set four main objectives to be achieved through this $A Z A M$ Kerja program. The four objectives are:

i) Omit poor households and poor individuals who are registered in the eKasih system by means of employment and offered job.

ii) Provide alternative sources to increase household income.

iii) Provide training opportunities for career adjustments.

iv) Conducting ongoing efforts through various changes in programs and motivate minds to encourage households to work and generate income.

This program is designed to provide an opportunity for the Head of Household (KIR) and Member of Household (AIR) from identified lower income groups that are interested in finding a job to improve their standard life of living. Departments concerned under the Ministry of Human Resources which directly involve in bringing AZAM Kerja Program to success are:

i) Labour Department (Peninsular Malaysia) for participants of AZAM Kerja from Peninsular Malaysia. 
ii) Department of Labour Sabah, Ministry of Human Resources for participants of $A Z A M$ Kerja from Sabah, and

iii) Department of Labour Sarawak, Ministry of Human Resources for participants of $A Z A M$ Kerja from Sarawak.

Participants of $A Z A M$ Kerja are identified through the registration in eKasih database system which has been developed by the ICU. Ministry of Women, Family and Community Development is a leading ministry that has conducted a survey questionnaire to participants of $1 A Z A M$ thus submitting the application on eKasih based on the results of the questionnaire. This application is only given to participants who registered under eKasih system. However, for reasons of health or death of the participant, the participant may be represented by a spouse or children by informing it to the headquarters of the Department of Labor. It will be filtered by the $1 A Z A M$ survey questionnaire conducted by the ministry. However, individuals who are not registered under eKasih portal can still obtain and apply for opportunities to find an employment of job through the jobsmalaysia.gov.my portal or by dealing directly with the Office of the State Labor and Manpower Branch in their respective areas of residence.

There are two type of aids provided in $A Z A M$ Kerja Program. These aids are:

i) Employment Assistance Program-This program will provide participants with at least three job offers from various sectors.

ii) Training and income generating programs-Employers or training provider that offers training opportunities to generate income for AZAM Kerja participants. Participants were also given the tools to generate income by employer or training provider to help participants generate income.

Selection employer or supervisor training is also conducted by the Ministry of Human Resources in accordance with the specified conditions. The conditions are as follows:

i) Employer or training provider must be registered with JobsMalaysia system.

ii) Employers or training providers offer various sector with minimum wage of RM 1000 per month.

iii) Employer' location must be within $10 \mathrm{~km}$ with the participant' resident.

iv) For location that is more than $10 \mathrm{~km}$, the employer must provide transportation and accommodation.

v) Training providers need to provide training, marketing and monitoring package.

Until January 1, 2011, the Ministry of Human Resources offers training and income generating programs such as tailoring, beauty and health, frozen foods and crafts based business. Training and income generating programs provide assistance in the form of assistance tool to participants monitored by the Ministry of Human Resources. Each participant need to undergo a training session, marketing packages and monitoring for six month run by training providers or any particular employment involved.

(ii) $A Z A M$ Tani

The second program that is also offered under $1 A Z A M$ is known as AZAM Tani. $A Z A M$ Tani provides opportunities to generate income through agriculture-based activities that deliver results or short-term returns. This agriculture-based activity in- 
cludes vegetables and fruits farming. Fertigation chili, mustard, pineapple and corn are some examples of agriculture-base activities that has been implemented in AZAM Tani program. As for livestock, freshwater fish, chicken and duck are the most general and common activities. The program is conducted both in groups and individually. This program was implemented in collaboration with the Ministry of Agriculture with the agency at the state level.

$A Z A M$ Tani project is a project that increases the income of the target group in which the economic project assistance are provided to the participants who are interested in the crop, livestock, fisheries, commercial plants, processing plants and agricultural services sectors. Similar to the AZAM Kerja Project, this project was also given to the head of household. However, if the head of household is unable to carry out the responsibility of the projects given due to medical, health conditions and so on, members of the household are encouraged to be responsible for the project implementations. AZAM Tani project under the Ministry of Agriculture and Agro-based Industry is responsible for all states in Peninsular Malaysia and the Federal Territory of Labuan only.

This is a project based on ability, skills and interests of the participants. Ministry of Agriculture and Agro-Based Industry Malaysia (MOA), departments and agencies will ensure that the project is viable by the participants based on sustainable income factors. For participants who are not productive, departments and agencies will determine the projects to be carried out by members of the household. If there is no member of the household that are capable, participants will be considered for passive assistance.

Projects carried out under AZAM Tani are performed in both individually or in groups. These projects are mostly projects that bring quick results ranging from one to six months of implementation. Previous studies have shown that agricultural growth has a larger effect on poverty reduction than the growth in other sectors [7]-[9]. There are variety of projects on agriculture and agro-based industries that are implemented under AZAM Tanis program (Table 1) [10].

Table 1. Projects on agriculture and agro-based industries under $A Z A M$ Tanis program.

\begin{tabular}{|c|c|}
\hline SECTOR & PROJECT TYPE \\
\hline Plantation & Short Term Plantation-corn, melons, mushrooms, chili and fertigation. \\
\hline Fishing & $\begin{array}{l}\text { Catfish, ornamental fish, fishing equipment, Fish farming in cages, breeding } \\
\text { freshwater fish and shrimp farming. }\end{array}$ \\
\hline Livestock & Swallow, honey bees, ducks and chickens. \\
\hline Processing & $\begin{array}{l}\text { Cake, dried fish, crackers, salted fish, traditional snacks, frozen foods, sauces, } \\
\text { chips, drinks and juice, salted eggs, coconut milk, coconut paste and coconut jelly. }\end{array}$ \\
\hline Product Business & $\begin{array}{l}\text { Selling sugarcane juice, soy products, fruits - sliced fruit, fried bananas, crackers, } \\
\text { nasi lemak, roti canai, kebab and fresh fish. }\end{array}$ \\
\hline Facilities/Equipment & Mobile kiosk, booth, three wheel motorcycle. \\
\hline Services & Lawn mower, poison spray, tractors, seed sprayers. \\
\hline Handicrafts & Handicrafts, seafood, shells, artificial bait for fishing. \\
\hline
\end{tabular}


$A Z A M$ Tani project package provided to participants include four areas namely:

i) Financial assistance worth RM 10,000 to each participant. This financial provision is intended to provide premises and infrastructure, seeds of livestock and plants, raw materials, machinery and other equipment needed to implement this program.

ii) Human capital development through training and guidance of the technical aspects are also provided. The examples of given training is training to control crops and livestock.

iii) Technology transfer from other departments and agencies to project participants also will be performed. The example of technology transfer is through the participation of government agencies such as the Department of Agriculture and Veterinary Services. Ministry of Agriculture \& Agro-Based Industry Malaysia

iv) Other facilities available are marketing support with engagement of government agencies such as the Federal Agricultural Marketing Authority (FAMA).

The project is implemented by 11 government departments and agencies, the Ministry of Agriculture and Agro-based Industry. The list of the agencies and departments responsible for implementation coordination and project coordinator for each state are as follows:

i) Perlis-Muda Agricultural Development Authority (MADA) and the Department of Agriculture (DOA).

ii) Kedah-Muda Agricultural Development Authority (MADA) and the Farmers Organization Authority (LPP).

iii) Pulau Pinang-Tabung Ekonomi Kumpulan Usaha Niaga (TEKUN) which focuses to the (Island site) and the Federal Agricultural Marketing Authority (FAMA), which focuses to the mainland section.

iv) Perak-Department of Agriculture (DOA).

v) Kuala Lumpur-Malaysian Agricultural Research and Development Institute (MARDI).

vi) Negeri Sembilan-Department of Fisheries (DOF).

vii) Melaka-Department of Fisheries (DOF).

viii) Johor-Malaysia Pineapple Industry Board (LPNM).

ix) Kelantan-Kemubu Agricultural Development Authority (KADA) and the Farmers' Organization Authority (FOA).

x) Labuan-Department of Agriculture (DOA).

xi) Terengganu-Fisheries Development Authority of Malaysia (LKIM).

xii) Pahang-Department of Veterinary Services (DVS).

xiii) Kuala Lumpur and Putrajaya-Federal Agriculture Marketing Authority (FAMA). The list of departments and agencies under the Ministry of Agriculture and Agrobased Industry involved in $A Z A M$ Tani Program are as follows:

i) Department of Agriculture (DOA).

ii) Department of Veterinary Services (DVS).

iii) Department of Fisheries (DOF).

iv) Malaysian Agricultural Research and Development Institute (MARDI). 
v) Federal Agricultural Marketing Authority (FAMA).

vi) Malaysian Pineapple Industry Board (LPNM).

vii) Farmers' Organization Authority (LPP).

viii) Fisheries Development Authority of Malaysia (LKIM).

ix) Muda Agricultural Development Authority (MADA).

x) Kemubu Agricultural Development Authority (KADA).

xi) Tenaga Ekonomi Kumpulan Usaha Niaga (TEKUN National).

xii) Agro Bank Malaysia (AGROBANK).

(iii) AZAM Niaga and AZAM Khidmat. Amanah Ikhtiar Malaysia (AIM)

Another program that is featured under $1 A Z A M$ is called $A Z A M$ Niaga. $A Z A M$ Niaga provides income-generating opportunities through small businesses with facilities for training and microcredit schemes. Among the types of businesses run by people involved in this program are the production of food and beverage products, handicrafts, and retail businesses. This program is carried out in collaboration with agencies such as AIM and the Ministry of Urban Wellbeing, Housing and Local Government (IPPF).

Apart from the three programs mentioned above, $1 A Z A M$ also has another program called $A Z A M$ Khidmat. AZAM Khidmat offer opportunities to generate services through the service area by providing training to participants to enable them to have certain skills such as self-care treatments and reflexology, massage and makeup bridal. The program is implemented in collaboration with Amanah Ikhtiar Malaysia (AIM) and the Ministry of Women, Family and Community Development.

AIM was established on September 17, 1987 by Trustee Act (1952). AIM is managed by a Board of Trustees consist of senior officials representing the Ministry of Finance, Economic Planning Unit (EPU), ICU, Ministry of Rural and Regional Development and several individuals appointed by their personal capacity. The main objective of establishing the AIM is to reduce poverty in Malaysia by financing small-scale or micro-credit used to finance economic activities that can increase revenue.

The main eligibility conditions that allowed participants to join AIM are:

i) Monthly household income not exceeding RM 2000 or RM 400 per capita.

ii) Ownership of assets is not exceeding RM 50,000.

iii) Only women are allowed to take part in this program.

iv) Formed a group of five participants who live in the same area. The five participants should not have any family relationship, able to bear the trusted and shared responsibility.

v) They need to attend short-term courses for five (5) days, $11 / 2$ hours a day.

The five-day course should be attended by the participants because the information on the conditions, rules and responsibilities as a member of AIM will be explained in detail to the participants in the course. The explanation given is to provide an understanding of the AIM and the relevant terms of the companions' agreement and regulations. This course may be conducted at any agreed upon place by group members and are typically used in the completion of the group itself.

Registration of participants for the AIM program is done through AIM staff visits to 
the applicants' residents after they have contacted their nearby authorized AIM officer in the respective regions. In addition to home visits, interviews were also conducted to determine the eligibility of the applicant who wishes to participate in the program.

Once accepted as a member, all members of AIM are required to attend weekly center meetings, shall compensate each week, making compulsory savings every week and implement the project properly.

This type of loan and the amount offered by AIM are as follows:

i. Economy funding:

o i-Mesra: Until RM 19,900

o i-Srikandi: RM 6000 - RM 19,900

o i-Wibawa: RM 5000

o i-Penyayang: RM 1000 - RM 5000

o i-Wawasan: RM 20,000 - RM 50,000

ii. Education funding:

o i-Bestari: Until RM 5000

iii. Various funding:

o i-Sejahtera: RM 2000 - RM 10,000

o Urban Micro Finance Program (KMB): RM 3000 to RM 20,000

(iv) AZAM Niaga and AZAM Khidmat: Ministry of Women, Family and Community Development.

Besides AIM, AZAM Niaga and AZAM Khidmat are also organized by the Ministry of Women, Family and Community Development. There are 20 business packages offered through the ministry which specializes in AZAM Niaga and AZAM Khidmat. The 20 business packages that are offered by AZAM Niaga and AZAM Khidmat are:

i) Steam Nasi Lemak Package

ii) Satay package

iii) Various fried packages

iv) Blended Ice Package

v) Sewing Package

vi) Barber Package

vii) Burger package

viii) Sugarcane Juice Packages

ix) Massage Package

x) Reflexology package

xi) Sweet Corn Package

xii) Air Batu Campur Package

xiii) Lawn Mower Package

xiv) Car Wash Package

xv) Otak-otak package

xvi) Bahulu Package

xvii) Char Koay Teow package

xviii) Roti John Package 


\section{xix) Chicken Wings Package \\ xx) Cendol Package}

Through this program, participants will have the opportunity to generate better income. In addition, participants will also be exposed to a lecture on financial management and basic skills training aid. Through this program, participants will be covered by insurance in the event should any unpredictable accident occurred during their business operations. Participants will also be supplied with budget books for the purpose of recording revenue.

Applications to join the program through the Ministry of Women, Family and Community Development can be done by filling the form directly at the ministry or through the Social Welfare Department (SWD) and the Department of Women Development (JPW) nearby the applicant. Form will be processed for two months depending on the allocation and approval of the top level. After receiving assistance, the monitoring process will be conducted three times a year on a regular basis to record increased in revenue and any difficulties encountered by participants.

\section{Result}

\section{(a) $1 A Z A M$ success}

According to the Ministry of Women, Family and Community Development, from the period of January, 2011 to March, 2015, a total of 140,976 participants joined $1 A Z A M$ with $65 \%$ or 91,290 participants were women. She said that out of 66.1 percent or 93,172 participants managed to increase their revenue at least RM300 for three consecutive months. In addition, for the period of December, 2009 to December, 2013, the ministry in collaboration with AIM managed to train and develop 5300 women entrepreneurs who have an income of at least RM 3500 per month for three (3) consecutive months [11].

According to the Auditor National's Report Series 3 in 2013, from 2010 until 2013, a total of RM 1.10 billion allocations for $1 A Z A M$ are channeled to implementing agencies under the Ministry of Women, Family and Community Development, Ministry of Agriculture and Agro-Based Industry, Ministry of Agriculture and Food Industry State of Sabah and Ministry of Welfare, Women and Family Development, Sarawak to be implemented throughout Malaysia. For Ministry of Welfare, Women and Family Development and Ministry of Agriculture and Agro-Based Industry, provisions are accepted under the provisions of "One Off" and Ministry of Welfare, Women and Family Development while each creates a Trust Account. Audit review found that the Ministry during the years 2010 to 2013, a total of RM 1101.45 million allocation received, a total of RM 895.24 million (81.28\%) was spent and the amount of RM206.21 million (18.73\%) remaining unspent. Among participants who had managed to improve their living life and successfully upgrade themselves from being in the poverty group by enrolling and participating into the $1 A Z A M$ program are as follows:

\section{(i) Livestock Project Kupang clustered}

According to the Auditor National Report (2013: 323-324), Mussel Farming Project 
by group was implemented on April 25, 2013. The project is in Kampung Kuala Masai, Pasir Gudang, Johor and was attended by 40 selected AZAM Tani participants among Aboriginal fishing communities who live in four (4) villages nearby. All participants of this project have been registered with e-Damak ${ }^{1}$ system, a system that has been certified by the Department of Orang Asli Development (JAKOA).

Under $1 A Z A M$, each participant will be given a sum of RM 10,000. The project is worth RM 0.40 million. Among the components of the project is to supply and install the mussel ropes made from materials such as plastic barrel floats, jelly can, polyethylene rope, concrete ballast and trawl nets wrapping the mussels rope. In addition, the cost of the project includes providing access roads and security facility (safety first). The implementer of this project is the Research Institute and the Malaysian Agricultural Development Institute (MARDI) while the controlling agency is South Johor Fishermen's Association (PNJS).

Until May, 2014, the implementing agency which is PNJS has made payment for three (3) times for each participant, on November 10, 2013, March 27, 2014 and May 11, 2014. Each payment for each of the month mentioned is RM 300 and the total amount received by each participant is RM 900. Moreover, most of the participants were employed in the project by PNJS executing agency. This group project has been successful in generating revenue and projects participants to benefit from the project's revenue.

(ii) My Kampung My Future (MKMF)

My Kampung My Future (MKMF) is also a project that is associated with $1 A Z A M$. The program initially started to be implementing in Kampung Merotai Besar, Tawau, Sabah, Kampung Gedong, Simunjan, Sarawak dan Kg Pulau Tiga, Kampung Gajah, Perak in 2012. Among the MKMF projects that have high value in Kampung Merotai Besar, Sabah is the Shrimp In Pond Farming Project handle by Ms Janariah Binti Kurus, as an anchor with seven (7) other young entrepreneurs who become her mentee. She initially had three (3) shrimp ponds have now grown to nine (9) ponds after she had receive a funding under the MKMF program. Accumulated income received by Ms Janariah from January to April, 2013 was amounted to RM 86,003.40. Building on this success, she is planning to start a crab breeding project as her next project in the future [12].

As for MKMF success story in Kampung Gedong, Simunjan, Sarawak, one of the participants in the village, Mr Amran Kamaziha, is operating the Chilli Fertigation Project. He has acted as an anchor to four (4) youth that has been selected to be his mentee starting on March, 2013. In the early stages, this anchor cultivated chili and eggplants conventionally and the average yield per tree is in the range of 500 gm to one (1) kilogram per season. After being introduced to the cultivation technology using fertigation system with four (4) rain shelter, the average of 600 trees has risen to more than 1.5 pounds per plant (until August, 2013) and this number is expected to increase twice to three (3) pounds per plant at the end of the harvest season in early September, ${ }^{1}$ Database systems established to monitor the situation of aboriginal peoples in Malaysia so they are not isolated from modernization. 
2013. The desire to learn and master the knowledge and skills in planting and fertigation has made this project as a technology promotion page where not less than 50 people have visited the project area since its inception. As technology development efforts, chili cultivation in fertigation to four (4) participants with 560 trees will begin early in September, 2013 [12].

Another MKMF project was implemented in Kampung Pulau Tiga, Kg Gajah, Perak. There, one of the participants who enrolled the program, Mr. Sharizad Shahrul Asmawi, has been working on Ornamental Fish Project. He initially started his business by using his savings of RM 20,000 in 2010 as a capital and now managed to owned an Arowana fish pond and stingrays Amazon marketed to China and Taiwan. Under MKMF he has elected ten (10) youths to become his mentee starting from February, 2013 [12].

In addition, young entrepreneurs from Kampung Pulau Tiga, Kampung Gajah Sub-District, Mr Ahmad Fauzi Bin Md Salleh has commercialized products based on tamarind. He has a tamarind tree farm area and only sells tamarind slices. The sales are upon request and depending on weather conditions, thus, has caused the leftovers tamarind to be thrown away. After joining the MKMF program, he has managed to produce 13 kinds of downstream products based on tamarind such as tamarind juice, jams and candied sold in pasar tani (open market) and carnival organized by FAMA and Agro Bazaar RTC in Perak. He gained an income of RM 20,000 within three (3) consecutive months since the beginning of his business which started on February, 2015. Now he had expanded his business by opening a branch of processing factory that will process juice cordial and will obtain for a halal, MeSTI (Makan Selama Teknologi Industri) and the Ministry of Health certifications [12].

\section{Conclusion}

Overall, the success of MKMF program received encouraging response from the selected villages, and there is also high demand from certain youth groups requesting to implement this program in their villages. Based on these critical factors, the Ministry is laying an effort to expand the NBOS program to other states, including the states of Kedah, Terengganu and Pahang. My Kampung My Future is expected to continuously provide benefit to the country in terms of improving agricultural production and non-agricultural commercial value. Thus, it could indirectly improve the quality of youth entrepreneur's income. In addition, this will also help and encourage them to remain in the village and develop their own villages for their interest and the future generation [12].

\section{Acknowledgements}

The authors would like to thank Ministry of Women, Family and Community Development and Ministry of Agriculture and Agro-Based Industry Malaysia for providing relevant references via online and hardcopy. Also to University Sains Malaysia for allocated the funding (304/PCGSS/6313184) to this research. 


\section{References}

[1] The World Bank (2015) Malaysia. http://data.worldbank.org/country/malaysia

[2] Gopal, P.S. and Malek, N.M. (2015) Breaking away from the Cycle of Poverty: The Case of Malaysian Poor. The Social Science Journal, 52, 34-39.

http://dx.doi.org/10.1016/j.soscij.2013.10.016

[3] Chamhuri, S. (2007) Enabling Policies for Poverty Alleviation: The Malaysian Experience. In: Nambiar, S., Ed., Reassessing Poverty in Malaysia, Wisdom House Publications, Kuala Lumpur.

[4] Ragayah, M.Z. (2010) Inclusiveness: A Fairer Way to Share the Economic Pie. National Economic Outlook Conference 2011-2012, Kuala Lumpur, 30 November-1 December 2012, 7.

[5] Shankaran, N. (2007) Capabilities and Poverty: Framing Poverty in Malaysia. In: Nambiar, S., Ed., Reassessing Poverty in Malaysia, Wisdom House Publications, Kuala Lumpur.

[6] The Department of Statistic Malaysia (2015) Poverty Profile. http://www.rurallink.gov.my/wp-content/uploads/2015/05/1-DATA-ASAS-MALAYSIA1.pdf

[7] de Janvry, A. and Sadoulet, E. (2010) Agricultural Growth and Poverty Reduction: Additional Evidence. The World Bank Research Observer, 25, 1-20. http://dx.doi.org/10.1093/wbro/lkp015

[8] Ravallion, M. and Datt, G. (1996) How Important to India's Poor Is the Sectoral Composition of Growth in India. World Bank Economic Review, 10, 1-25. http://dx.doi.org/10.1093/wber/10.1.1

[9] Warr, P. (2003) Poverty and Economic Growth in India. In: Kalirajan, K. and Shankar, U., Eds., Economic Reform and the Liberalization of the Indian Economy, Edward Elgar, Cheltenham.

[10] KPWKM [Ministry of Women, Family and Community Development] (2014) Program 1Azam. http://mybajet.my/ms/tag/1azam

[11] MyBajet 2015 (2014) 168,946 e-Kasih Participants Success in Increasing Income Level. http://mybajet.my/ms/168946-ekasih-participants-see-increase-in-household-income

[12] MOA [Ministry of Agriculture and Agro-Based Industry Malaysia] (2015) My Kampung My Future: National Blue Ocean Strategy.

http://www.moa.gov.my/en/my-kampung-my-future 
Submit or recommend next manuscript to SCIRP and we will provide best service for you:

Accepting pre-submission inquiries through Email, Facebook, LinkedIn, Twitter, etc.

A wide selection of journals (inclusive of 9 subjects, more than 200 journals)

Providing 24-hour high-quality service

User-friendly online submission system

Fair and swift peer-review system

Efficient typesetting and proofreading procedure

Display of the result of downloads and visits, as well as the number of cited articles

Maximum dissemination of your research work

Submit your manuscript at: http://papersubmission.scirp.org/

Or contact jhrss@scirp.org 